\title{
Inflation Targeting Pillars: Transparency and Accountability
}

Charles Freedman and Douglas Laxton 


\title{
IMF Working Paper
}

\author{
Research Department
}

\section{Inflation Targeting Pillars: Transparency and Accountability}

\author{
Prepared by Charles Freedman ${ }^{1}$ and Douglas Laxton
}

December 2009

\begin{abstract}
This Working Paper should not be reported as representing the views of the IMF. The views expressed in this Working Paper are those of the author(s) and do not necessarily represent those of the IMF or IMF policy. Working Papers describe research in progress by the author(s) and are published to elicit comments and to further debate.

This is the fourth chapter of a forthcoming monograph entitled "On Implementing Full-Fledged InflationTargeting Regimes: Saying What You Do and Doing What You Say." It examines a number of issues related to transparency and accountability in an inflation-targeting regime. It first looks at the factors behind the move to increased transparency in recent years and the important role of a communications strategy in transparency. It then turns to the role of the forecast in communications, how risks surrounding the forecast are communicated, and whether there should be limits on what is made public. It concludes with a short discussion of accountability.
\end{abstract}

JEL Classification Numbers: E30, E31, E58

Keywords: Inflation Targeting, Monetary Policy

Author's E-Mail Address: cfreedma@,connect.carleton.ca; dlaxton@imf.org

\footnotetext{
${ }^{1}$ Charles Freedman is Scholar in Residence in the Economics Department, Carleton University, Ottawa, Canada. Douglas Laxton is the Head of the Economic Modeling Unit in the Research Department. This paper represents the fourth chapter of a book that is being prepared by Charles Freedman, Douglas Laxton and Inci Ötker-Robe On Developing a Full-Fledged Inflation Targeting Regime: Doing What You Say and Saying What you Do. See Appendix for a summary of the book. The authors wish to thank a large number of colleagues at the Fund and other policymaking institutions for encouraging us to do this work, and Scott Roger and Lars Svensson for their comments. We also gratefully acknowledge the invaluable support of Heesun Kiem and Susanna Mursula for their research assistance, and Laura Leon for her help in the preparation of the paper. The views expressed here are those of the authors and do not necessarily reflect the position of the International Monetary Fund. The model simulation programs used in the book can be downloaded from www.douglaslaxton.org. Correspondence:

cfreedma@,connect.carleton.ca; dlaxton@,imf.org
} 


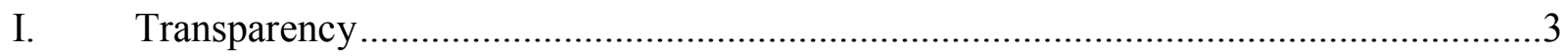

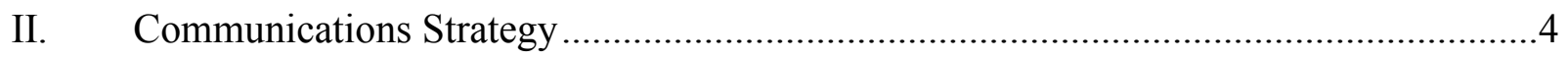

III. Role of the Forecast in Communications............................................................. 7

IV. Communicating the Risks Surrounding the Forecast.............................................. 10

V. Should There Be Limits to What is Made Public? ......................................................11

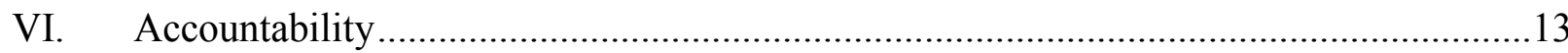

Appendix: Background and Brief Summary of the Books ................................................ 15

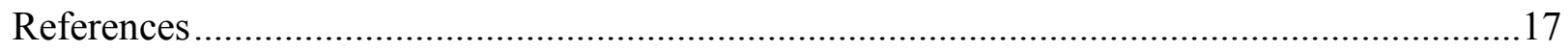

Figure

1. Changes in 12-Month Interest Rates Following Revisions in Policy Rate.....................10 


\section{Transparency}

There are two key factors behind the move to increased transparency on the part of central banks. $^{2}$ The first is the relationship between transparency and the effectiveness of monetary policy. The second is the link between transparency and accountability.

The way in which monetary policy is conducted by central banks has changed significantly in recent years. Not too long ago, central banks said relatively little about their monetary policy and allowed their actions to speak for themselves. Today, in contrast, central banks are very explicit in setting out the objectives of policy, the way in which they view the operation of the transmission mechanism between their policy actions and their goal variables, their outlook for economic activity and inflation, and their setting of the policy interest rate. It is now generally believed in the central banking community that this increased transparency improves the functioning of monetary policy in a number of dimensions.

The first dimension involves the understanding of the general public, both directly and through the media. Like all public policies, monetary policy benefits from increased public support and understanding. In particular, monetary policy, which at times involves the need to take tightening actions to prevent the economy from overheating, would find itself the subject of considerable public criticism if the public did not understand the reason for policy actions. The key point in developing such an understanding is to make clear what monetary policy can do, as well as what it cannot do. Thus, central banks should emphasize that the role of monetary policy is to control inflation in the medium to long run and that an environment of low inflation will help the economy to achieve a higher level or rate of growth of productivity.

In addition to generating broad public support for the goal of low inflation, transparency (along with the credibility of policy) can contribute to behavior that will facilitate the achievement of the goal. Thus, in the case of demand and supply shocks, having inflation expectations partly anchored to the inflation target lessens the need for the central bank to take action. For example, a positive temporary demand shock requires an increase in the policy interest rate to act against both the shock itself and any increase in inflation expectations that results from the demand shock. If there is little or no increase in inflation expectations, the required increase in the policy interest rate to offset the shock will be smaller. Similarly, a positive temporary price shock typically requires central bank action to prevent its effect from spreading and thereby influencing inflation expectations. If the latter are anchored, there will be less need for an offsetting central bank policy action. In addition, when medium-term to longer-term inflation expectations are well anchored, labor negotiations are less contentious and both sides are aware that they are negotiating about real wages and not about the likely future rate of inflation. In short, wage and price setting that is done in the context of an environment of confidently held expectations of low and stable inflation will make the task of the central bank easier.

\footnotetext{
${ }^{2}$ This section draws heavily on Freedman (2002). See also Woodford (2005).
} 
The second dimension of the relationship between transparency and the functioning of monetary policy involves the behavior of participants in financial markets. When financial markets understand and anticipate the actions of the central bank, the first steps in the transmission mechanism between policy actions and economic activity and inflation work more smoothly.

For example, when the central bank and market participants have a similar interpretation of factors affecting the economic outlook, data releases will tend to lead to movements in market interest rates (and the exchange rate) in advance of, and consistent with, the policy actions that are subsequently taken by the central bank. Thus, new data indicating increased pressures on capacity and, hence, an increased likelihood of higher future inflation will result in higher interest rates across much of the yield curve, while signs of weakness in the economy and an increased likelihood of lower future inflation will result in lower interest rates.

It is worth emphasizing that central banks should not and do not simply follow the financial market. If views differ between the central bank and the market as to the likely outlook and the appropriate policy, the central bank must follow its own best judgment and explain to the market the reasons for its actions. The enhanced transparency and improved communications of recent years reduce the likelihood of sharply different views as to appropriate policy actions, although they do not entirely eliminate it. In short, if market expectations are broadly in line with the direction of policy, there is likely to be less volatility in financial markets and smoother incorporation of policy actions into interest rates and exchange rates.

\section{Communications Strategy}

Communications play an important role in the transmission of the views of the central bank to the public and to markets. Hence, a great deal of attention is now paid to the way that central banks present their key messages - see Blinder and others (2001), Jenkins (2001), Heenan and others (2006), Blinder and others (2008) and Jeanneau (2009). Improving the effectiveness of monetary policy through greater transparency requires proactive and well-planned communications.

What should be communicated? One important message is that inflation is not conducive to a well-functioning economy and that the objective of low and stable inflation is a means to an end - the end being a healthy, growing economy that provides jobs and higher living standards in an environment of relative stability. The emphasis should be on the contribution that monetary policy can make to the objective of achieving low and stable inflation. Examples from postwar economic history that focus on the poor performance of the economy at times of high inflation and its better performance at times of low inflation can be helpful in this regard. Another important message relates to what monetary policy cannot do-sound monetary policy is necessary but not sufficient to the achievement of economic goals. For example, the central bank should communicate to the public the notion that sound fiscal policy is essential to the efficient operation of monetary policy, and that structural policies and 
measures to liberalize the economy are crucial for economic development. As well, it should explain that a monetary policy aimed at inflation control will tend to moderate the economic cycle, although it cannot eliminate it.

When introducing an IT framework, the central bank should initially try to communicate as good an understanding as possible of the way in which IT will be conducted. This means providing technical and non-technical discussions of the policy goals, the central bank's current understanding of the transmission mechanism (including the expectation that it will change over time as the economy is transformed), and explanations of its choice of key design parameters of the IT regime. Among the most important aspects of this part of the communications strategy is providing a clear explanation of how the central bank will respond to the impact of demand and supply shocks on forecast inflation. The central bank will need to emphasize (i) that its policy approach will focus on the medium term; (ii) that the forecast rate of inflation will play a critical role over the policy horizon; and (iii) that its view of the forecast inflation rate will change over time as a result of new information (including unforeseen shocks) and of changes in its interpretation of economic developments. In its ongoing policy discussions with domestic and international financial markets, the central bank's changing views on the outlook for growth and inflation will be a central element. And the central bank should announce the setting for its policy interest rate as soon as feasible after the decision is made (including circumstances in which there is no change in the policy interest rate).

In developing a communication strategy, the central bank has to take into account the necessity of aiming its messages at multiple audiences. These include the general public, financial markets, the media (including the experts that the media rely upon for comment), Parliament and the government, and academics. It is important to tailor the way that the messages are delivered to the particular audience being addressed, while ensuring that there is consistency of the messages across the various audiences.

How should the central bank's views be communicated? The major mechanism for communicating its views is a Monetary Policy Report or Inflation Report, published between 2 and 4 times a year. This document enables the central bank to set out recent global and domestic output and inflation developments, its outlook for the future, the implications of the outlook for the setting of the policy interest rate, and the risks to the outlook and to the projected interest rate path.

There are a number of issues related to how the Report is structured. It can be a short (30 pages) or long (70 or 80 pages) document, depending on the amount of detail included. The first major chapter might be devoted to recent global and domestic developments in output and inflation, focusing on the most important driving forces. The second major chapter might explain recent global and domestic developments on the financial side, with particular emphasis on the reasons for the interest rate decisions taken by the central bank since its previous report. The final major chapter might set out the outlook for output, inflation, the interest rate implications of the outlook, and the major risks to the outlook. 
The amount of detail and the precision with which the outlook is described in the Report is decided by the Monetary Policy Committee (MPC). The tendency has increasingly been to focus on broad variables, such as consumption, investment, and the trade balance, and to avoid discussion of more detailed variables, such as household expenditures on specific types of services, for example, except where they might illustrate a broader phenomenon. The Report can provide a table with quarterly, semi-annual or annual projected growth rates for the next two or three years, or a more qualitative outlook. As an example of the latter, the Report might refer to inflation slowing to "just above the target at the end of two years," rather than "increasing at a rate of 2.25 percent at the end of 2012."

It is crucial for the Report to provide a clear indication of the central bank's views of the major forces driving economic developments and the risks surrounding that view. This will give the markets a much better understanding of which developments will be central to the bank's thinking as it makes interest rate decisions over time. The markets will also be better informed about the types of unexpected developments that would change the central bank's views, and how it would react to new information in the areas where it feels most uncertain.

To help in the communication of the central bank's main messages to the public and to financial markets, the central bank should provide an executive summary at the beginning of the Report or a short (four or five pages) stand-alone summary version of the Report. Both the Report and the executive summary should focus on the three or four key messages that the central bank wishes to communicate. To ensure rapid dissemination of these main messages to financial markets worldwide, an English translation of the executive summary should be released at the same time as the Report is published. The English translation of the body of the Report could then be released with some short delay.

To give the wire services and the specialized financial journalists time to absorb the Report before writing their accounts, they could be offered a lockup prior to the release of the Report, perhaps with access to senior staff to provide guidance on technical issues in the Report. Consideration should also be given to having the governor or the deputy governor responsible for the forecast process give a press conference later that day. He or she could provide a short summary of the main messages in the Report in an opening statement and then take questions. Subsequently, members of the MPC and senior staff could meet with a business people, union leaders, and economists in various domestic financial centers and perhaps in major financial centers abroad.

There are also a number of other means by which the central bank can get its messages out to the public. These include press releases following each decision-making meeting of the MPC that discuss briefly the decision and the reasons for it, release of MPC minutes, meetings with interested groups following the publication of the Report, appearances before Parliament, speeches to various audiences, and lectures to academics. Ideally, all these means of communicating should be treated as an integrated whole, complementing each other to communicate central bank messages most effectively. Otherwise, there is a risk of over-communicating and transmitting different messages through the various communication channels. 
Table 2 in Roger and Stone (2005) shows that about half of those central banks in which there are interest rate setting meetings of the MPC on a previously announced schedule release MPC minutes, while the other half have chosen not to release MPC minutes. The latter rely upon the discussion in the Monetary Policy Report or Inflation Report to inform the public of the key issues that the MPC faced in coming to its interest rate decision.

How often should the central bank communicate? While there has been a tendency to increased levels of communication in recent years, central banks typically place an embargo on speeches and other communications with the market by MPC members for some period, often one week, before MPC meetings. An important issue with respect to the frequency of central bank communications is whether the MPC should try to communicate its changes of view about the outlook in response to new information released between interest rate setting dates. There are good arguments against so doing. The flow of information within the month or six weeks between meetings is typically not so significant as to merit the effort on the part of the MPC to reach a new view, and there is a risk of an over-reaction by financial markets to the announcement of a new view.

\section{Role of the Forecast in Communications}

In most IT central banks, a forecast covering the major macroeconomic aggregates and inflation plays a key role in central bank publications and in the communications strategy. As monetary policy has become more forward-looking and more preemptive in its actions, the central bank's views on how future output and inflation will be affected by global and domestic demand and supply shocks has become a central element in its decision making and in its communications. The projected outlook forms the basis for the discussion around short-term decision making and around the medium-term strategy of the central bank. That is, given the objectives of the central bank, given the current view of the central bank with respect to the country's economic and inflation prospects, and given its understanding of the transmission mechanism between its actions and economic and inflation developments, the forecast allows the MPC (or its equivalent) and the central bank staff to determine the path or paths for the policy instrument that would lead to the best outcomes. These are of course conditional on what is known at the time that the forecast is prepared and will change as new information becomes available and as the understanding of economic relationships by the central bank changes.

There are three principal ways in which central banks approach the convention underlying the economic forecast on which policy is based. (1) Many central banks, such as the Bank of England, base their forecast on the assumption of unchanged interest rates or on the path of policy rates implicit in the term structure of market interest rates. ${ }^{3}$ (2) Some other central banks prepare a forecast in which the interest rates are completely endogenous, but do not

\footnotetext{
${ }^{3}$ For central banks in small open economies, there is also the issue of whether to establish an exchange rate convention in developing and communicating its projection for the economy.
} 
make public the interest rate path on which their output and inflation forecast is based. They tend to use qualitative terms such as "inject more monetary stimulus" or "gradually withdraw the existing level of monetary stimulus" to give markets some idea of the path for interest rates expected by the central bank, without being too explicit. (3) Four central banks whose forecast is based on an endogenous interest rate path currently publish an explicit projected path for interest rates - the central banks of New Zealand, Norway, Sweden and the Czech Republic.

The main problem with basing a forecast on the assumption of unchanged interest rates or the market forecast of interest rates is that such forecasts are internally inconsistent. This problem becomes very evident when working with models where expectations include model-consistent elements-see Isard and Laxton (2000). It is clearly better to have a fully consistent forecast with interest rates endogenous. Note that for inflation-targeting central banks, the endogenous interest rate path will be determined by the requirement that inflation returns to its target over the policy horizon. Within the family of paths that satisfy this condition, the MPC will choose a path that "looks good" as its base case, i.e. a path that results in a good outcome for the economy, with output around potential at the end of the policy horizon, inflation approaching its target, and movements of key economic variables that are not unduly volatile along the path ${ }^{4}$.

For the central banks that base their outlook on an endogenous interest rate scenario, there are advantages and disadvantages to publishing the base-case path for interest rates. Given that central banks try to manage expectations of future interest rate movements in order to influence interest rates beyond the short term, publication of an explicit interest rate scenario can be very helpful in this regard. Svensson (2007) explained the Riksbank's recent decision to publish its interest rate forecast as follows.

"Monetary policy works by affecting expectations about the future interest rate. It is the entire interest rate path that is important for future inflation and resource utilization, not merely the interest rate over the coming weeks. The Riksbank has therefore come to the conclusion that the only right thing is to explicitly discuss the interest rate path and to choose a particular path as the main forecast, as well as publishing the interest rate path and justifying its selection. This is in my opinion the most effective way of conducting monetary policy. Not to discuss and select a particular interest rate path as a main forecast would be an incomplete decision-making process. Not to publish the interest rate forecast would be to hide the most important information."

And not publishing the endogenous interest rate scenario leaves the central bank with the awkwardness of talking about a particular outlook for output and inflation but leaving the public unclear or not very clear about what interest rate path underlies it.

The principal risk in publishing an explicit path for projected interest rates appears to be that at least some market participants might believe that the central bank is making a commitment

\footnotetext{
${ }^{4}$ Alichi and others (2009) provides a model that uses a loss function to determine an optimal path for the policy rate. For the code see www.douglaslaxton.org.
} 
to bring about the projected interest rate path regardless of changing developments. Indeed, one of the most important messages that the central bank has to communicate to the public is that the forecast or outlook in the Report is conditional upon information available at the time of writing and will almost certainly change as new information (and new interpretations) become available. The experience in New Zealand (since 1997) and Norway (since 2005) suggests that the financial market participants learn fairly quickly about the conditional nature of the forecast interest rate path..$^{5}$ Of course, it does take some time for the market to learn, and it is important for a central bank deciding to publish the interest rate path underlying the forecast to be very diligent about explaining the conditional nature of the path. For example, when the Riksbank, decided to publish the interest rate scenario underlying its forecast in February 2007, the Governor noted (Ingves, 2007) that "it is important to emphasize ... that we are talking about a forecast for the repo rate. This is the repo rate development that currently appears most likely given the information available. We are not making any promises. The fact that the Riksbank is presenting its own interest rate path does not mean that we are laying down a policy that we will commit ourselves to following." While it appears that the markets learn over time how to interpret the conditionality of the interest rate path, there may be an awkward period while they are on of the learning curve. As Svensson (2007) put it in the context of the Swedish situation, "it is natural that it will take some time for the new system to become established."

The experience of the Norges Bank before and after it began to publish its forecast interest rate path in the Inflation Report of November 2005 illustrates one of the advantages of the increase in transparency that accompanies the publication of the forecast path by a central bank. Figure 1 shows the change in the 12-month interest rate that followed the announcement of a revision in the policy rate by the bank. It is apparent that the size of the change was about twice as large on average in the period before the Norges Bank published the forecast interest rate path than in the subsequent period. Moreover, there were a considerable number of changes in the 12-month interest rate on the order of 25 basis points in the earlier period, but the maximum size of the change in the later period was about half that size. The conclusion that we would draw from this evidence is that the greater understanding on the part of financial market participants that resulted from the increase in transparency considerably reduced the surprise component of the change in the policy interest rate, since publication of the interest rate path gives financial markets a much better idea of the policy intentions of the central bank over time. ${ }^{6}$

\footnotetext{
${ }^{5}$ See Archer (2005) for a discussion of the New Zealand experience.

${ }^{6}$ While the FOMC does not publish an interest rate projection, FOMC minutes since early 2008 have included a summary of the economic projections of the members of the Board of Governors and the presidents of the Federal Reserve Banks, all of whom participate in the deliberations of the FOMC. These economic projections are issued four times a year, with a horizon of around three years, and cover real GDP growth, the unemployment rate, core price inflation and overall inflation. A detailed discussion of the key influences shaping the FOMC outlook is provided, and the forecast discussion includes the FOMC participants' qualitative assessments of the amount of uncertainty and the balance of that uncertainty in the economic outlook. The dispersion of forecasts among the FOMC participants is also described in some detail.
} 


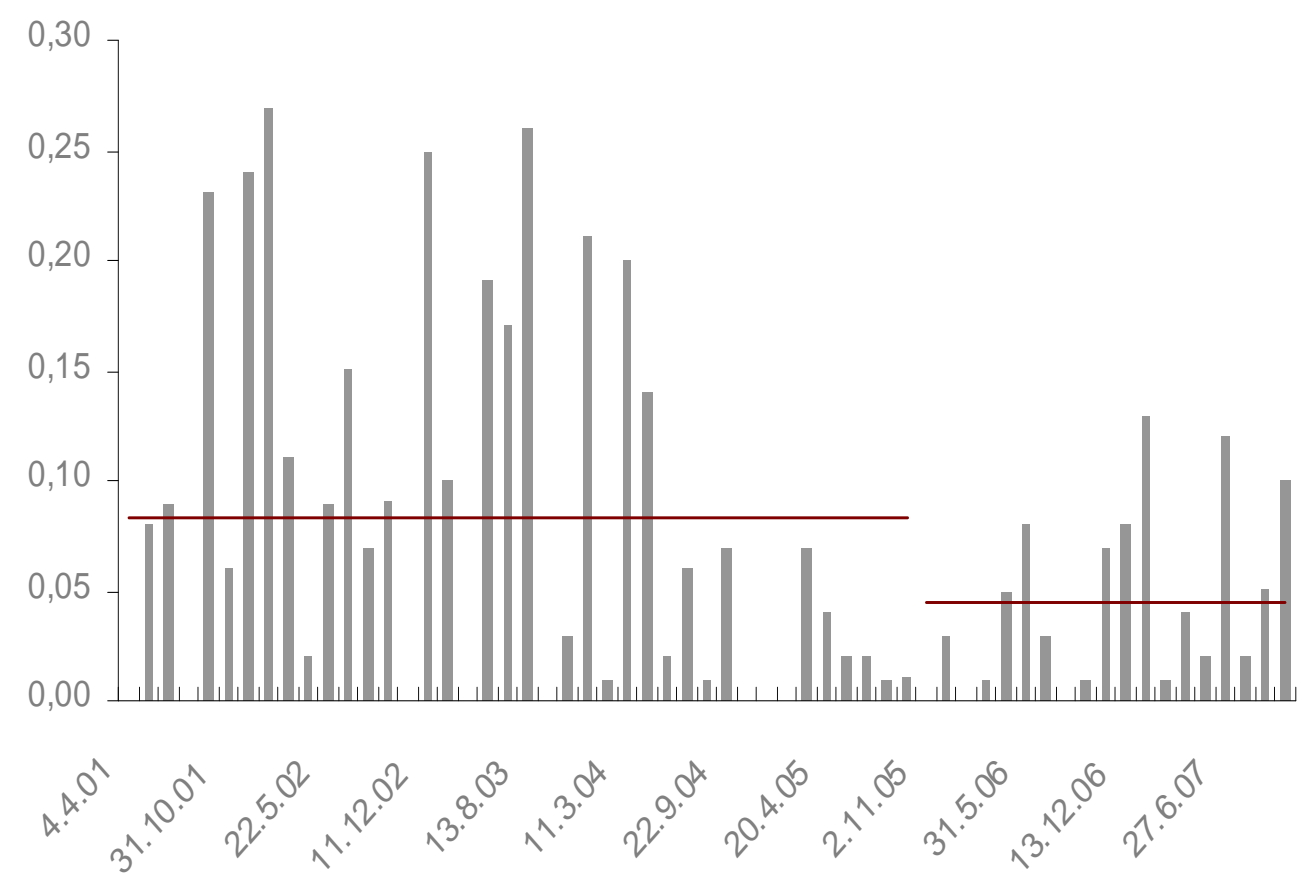

\section{Communicating the Risks Surrounding the Forecast}

One issue with which central banks continue to struggle is how best to characterize and communicate the risks around their baseline case forecast. Some, such as the Bank of England and the Riksbank, present a form of probability distribution that is intended to indicate the variance around the central forecast (a fan chart). Others, such as the Federal Reserve and the Bank of Canada, are more qualitative in their presentation of the balance of risks. But no central bank has been completely successful thus far in communicating the nature of the risks surrounding its outlook for the economy and inflation.

Many central banks release the minutes of MPC meetings to help communicate the uncertainties facing monetary policymakers. Others rely upon discussions of risks and uncertainties in the Monetary Report or Inflation Report to achieve the same result. While the fan chart is a useful way of describing the risks surrounding the base case or central forecast, a verbal description of the main risks perceived by the MPC and how the central bank might respond should those risks eventuate can also be a very effective method of communicating risks to the public.

If MPC minutes are published, the discussion of the differences in views of members of the MPC has to be framed in such a way as to promote increased understanding of the issues confronting the MPC, without leaving the impression that the MPC debate is confused. If the 
outcome of the vote on the interest rate decision is published, the members of the MPC will not all be able to focus only on the consensus outlook in their speeches. If they did, commentators and markets would wonder why all members of the MPC had the same view of the economic outlook when there was a split vote.

\section{Should There Be Limits to What Is Made Public?}

On the surface, this seems like an odd question. Can there ever be too much of a good thing? But as one reflects on the nature of transparency and communications, it becomes clear that certain steps in the direction of increased transparency could actually be counterproductive. Let us begin with an admittedly extreme example, turn to the principle at issue, and then return to some examples.

Should the policymaking body's deliberations before its decisions be televised or Web-cast? Even strong proponents of transparency come to the conclusion that such an initiative could be harmful for a number of reasons. First, policymakers could be inhibited from taking different points of view in the course of the discussion (i.e., playing devil's advocate). Second, it would make it more difficult for them to change their minds on the appropriate decision for the policy interest rate as the debate progressed and as different perspectives on the issue were discussed, since they would appear to be "waffling" on the decision. Third, making the deliberations public would likely lead to participants making more formal presentations (with perhaps a more entrenched initial position), replacing the more informal discussion in which the dynamic of the debate plays an important role in arriving at a decision. ${ }^{7}$ In short, the view that opening the deliberations to the public could well lead to a deterioration in the quality of the decision-making process has acted to prevent such a development even in those central banks that are the most enthusiastic supporters of transparency. ${ }^{8}$

Let us now examine the question of the limits of transparency from a broader perspective, drawing on an interesting and insightful paper by Bernhard Winkler (2002). ${ }^{9}$ Winkler argues that "in a world where-unlike in most standard economic models - cognitive limits matter, more information and greater detail does not by itself translate into greater transparency and better understanding, nor does it necessarily lead to more efficient decision-making." Winkler notes that there are several aspects of transparency, which may possibly conflict with one another. These include (i) openness, or the amount and precision of information provided; (ii) clarity in the presentation and interpretation of information; (iii) common understanding by

\footnotetext{
${ }^{7}$ In the United States, presentations at FOMC meetings by Board members and Reserve Bank presidents appear to have become somewhat more formal since 1993. In the fall of that year, the FOMC was made aware that the transcripts of the tape recording of the meetings since March 1976 had been retained. The FOMC subsequently decided that lightly edited verbatim transcripts of the meetings would be released with a five-year delay.

${ }^{8}$ See Blinder and others (2001) for a detailed discussion of this issue.

${ }^{9}$ See also Mishkin (2004) and Edey and Stone (2004).
} 
the sender and receiver of information; and (iv) honesty, or the correspondence of the internal framework of analysis with the presentation used for external communication.

As an example of potential conflict, we can compare openness and clarity. Central bank projections typically produce time paths for dozens or even hundreds of economic variables. Yet most central banks communicate to the public their quantitative outlook only for the broadest economic measures, such as output and inflation. ${ }^{10}$ This reflects the view that increased openness, in the sense of presenting enormous amounts of detail, would reduce the clarity of the central bank's message about future developments rather than increase it.

The notion of "honesty" in the correspondence of the internal framework of analysis and external communications also gives rise to some interesting issues. Economists, whether in universities or markets, would like central banks to be more explicit in setting out their reaction function to various contingencies. But central banks, while they spend a lot of time considering the appropriate response to various shocks, do not have an explicit, quantitative pre-agreed reaction function for every type of shock. To quote John Vickers (1998): "In situations of any complexity, there is a tension between a complete contract (i.e. one that specifies what is to happen in every eventuality) and having a good contract (i.e. one that entails good decisions in every eventuality). If the same is true for policy reaction functions, then residual discretion is sensible and so residual uncertainty is inevitable."

One reason that it is not possible to develop a simple reaction function is that there is no model of the economy that is universally accepted. ${ }^{11}$ With model uncertainty, there cannot be a simple reaction function, especially when different weights are attached to the projections from the various models in different circumstances. One of the perceived advantages of the Taylor rule is that it is robust across models. But while the Taylor rule can be useful as an indicator of policy in many circumstances, it is not a reaction function that sets out a monetary policy response to all contingencies. A second reason that there cannot be a simple reaction function is that the information used in coming to a decision involves more variables than can be incorporated in any such function. For example, in the early 1990s, the reluctance of commercial banks to extend loans (Chairman Greenspan's "headwinds") played an important role in the Federal Reserve's conduct of policy. In the latter part of the 1990s, the increased rate of growth of productivity operated through a number of channels to affect economic behavior and thereby to influence the Federal Reserve's decision-making. And, subsequently, the confidence of firms and households in light of the terrorist attacks of September 11, 2001 played an important role. While a simple relationship such as a Taylor rule can be a helpful guide to policymaking, it cannot incorporate all the factors that feed into the decision-making process (especially in an open economy).

\footnotetext{
${ }^{10}$ There is often considerable qualitative discussion of some of the components of these broad measures, but most cenral banks do not give precise estimates of their projections of these components.

${ }^{11}$ See, for example, Bank of England (1999) for the various models that the Bank used in its policy formulation.
} 


\section{Accountability}

The second key factor motivating the trend to greater transparency is the tendency toward greater accountability, an important element in the framework supporting the independence of central banks. Increasingly around the world, central banks are being given responsibility for carrying out monetary policy in the context of objectives that are defined in legislation or treaty and/or agreed upon by the government and central bank. As non-elected bodies, central banks are typically held accountable to government or parliament or the general public for their stewardship of policy. In order for this accountability to be effective, the oversight body must have sufficient information to evaluate the conduct of policy by the central bank. Such information is provided by central banks in the context of their overall communications strategy, and the need to provide this information has played an important role in the increased transparency of monetary policy.

The accountability of policymakers will thus require them to regularly provide information on (i) where inflation is with respect to the target and why the outcome is different from that previously expected; (ii) what the outlook for inflation is in the changed circumstances; and (iii) what can be done under the circumstances to bring inflation back to the target. This type of explanation is typically done in the Monetary Policy Report or Inflation Report. Another element of accountability is the required appearance of the governor and members of the MPC before Parliament or before one of its committees to explain the monetary policy framework, the central bank's views on economic developments, and its recent interest rate actions. Regular public speeches by the governor and members of the MPC provide another element of accountability. Finally, a longer-term perspective on the success of the central bank in achieving the inflation target could be provided in a box included perhaps once a year in the Monetary Policy or Inflation Report.

In the Bank of England, there is a formal arrangement in which the Governor is required to write an open letter to the Chancellor of the Exchequer if the rate of inflation moves more than one percentage point on either side of the target. The letter will set out the reasons why inflation has increased or fallen to such an extent, the policy actions that the Bank is taking to deal with it, the period within which the Bank expects inflation to return to the target, and how this approach meets the Government's monetary policy objectives. Some other central banks have similar arrangements. Nonetheless, circumstances in which inflation move outside a target band should not necessarily be considered as a sign of failure. Indeed, the central bank should make it clear that it expects to be within the band most of the time but not all of the time. The band is like a confidence interval in which outcomes are expected to fall only a certain proportion of the time. ${ }^{12}$ In fact, a success rate of 100 percent indicates either that the underlying economic arrangements or behavioral characteristics of the economic participants have changed since the decision was made about the size of the band, or that the central bank

\footnotetext{
${ }^{12}$ See Freedman and Laxton (2009b) for further discussion of the role of a target band or range.
} 
is putting little or no weight on the output variability term in the loss function. ${ }^{13}$ What is more important than succeeding in having an extremely high proportion of outcomes falling in the band is to be able to provide a convincing explanation of why the shocks that have buffeted the economy have caused the rate of inflation to fall outside the band, why such a result could not have been foreseen and prevented, and what was being done to counteract the outcome and to gradually bring inflation back to the target.

${ }^{13}$ One way in which external observers could judge whether the central bank is striking a good balance between stabilizing inflation and stabilizing output would be for the central bank to publish alternative scenarios for the policy interest rate and their consequences for the forecasts of inflation and output. 
Appendix: Background and Brief Summary of the Book On Implementing Full-Fledged Inflation Targeting Regimes: Saying What You Do and Doing What you Say

\section{Background Information:}

The book grew out of a series of inflation-targeting (IT) and macro-modeling workshops that were designed to introduce central bankers and IMF staff members to the subject. The workshops covered many of the practical aspects of IT and were taught by several lecturers who had considerable central-banking experience either working under an IT regime or helping other central banks set up an IT regime. They also provided an opportunity for central banks at different stages of implementing IT regimes to share their experiences. The external workshops were organized on a regional basis and included Mexico (2001), Finland (2001), Turkey (2002), Finland (2003), Ukraine (2004), Turkey (2005), Thailand (2006) and Morocco (2007). The internal workshops were organized by the IMF Institute each year since 2006. The external workshops were all sponsored in part by the host central bank and organized by staff in the Fund's Research Department and Monetary and Capital Markets Department.

The editors and authors would like to thank a large number of people for contributing to the workshops and the material that is presented in the book. In particular, we owe a great debt to a few IT central banks that willingly gave us access to some of their most talented people. This list includes Tore Anders Husebø (formerly Norges Bank), Jaromir Benes (formerly Czech National Bank and Reserve Bank of New Zealand and currently IMF), Aaron Drew (Reserve Bank of New Zealand), David Hargreaves (Reserve Bank of New Zealand), Jaromir Hurnik (Czech National Bank), Ondra Kamenik (Czech National Bank and IMF), Tiff Macklem (formerly Bank of Canada), Øistein Røisland (Norges Bank), David Rose (formerly Bank of Canada), Alasdair Scott (formerly Reserve Bank of New Zealand and Bank of England, currently IMF), Kristen Solberg-Johansen (Norges Bank), David Vavra (formerly Czech National Bank, currently IMF) and Jan Vlcek (Czech National Bank). As well, we would like to thank Andy Berg, Philippe Karam, Michael Kumhof and Papa N'Diaye of the IMF for their contribution to the workshops.

\section{Brief Summary of the Chapters:}

Chapter 2. Why Inflation Targeting? Freedman and Laxton (2009a) contains background considerations on why central banks have chosen low inflation as their policy goal and why so many countries have chosen inflation targeting as a framework for achieving that goal.

Chapter 3. Inflation Targeting Parameters: Freedman and Laxton (2009b) discusses design parameters - (i) the definition of target variable; (ii) the potential role of core inflation measures; (iii) the advantages and disadvantages of point targets, point targets with a band, and range targets; (iv) the choice of the long-run target inflation rate; (v) the target horizon; and (vi) the loss function and policy horizon.

Chapter 4. Inflation Targeting Pillars: Transparency and Accountability: Freedman and Laxton (2009c) discusses issues related to transparency, communications, and accountability. 
Chapter 5. Important Elements for Emerging Economies: Freedman and Ötker-Robe (2009a) discusses important elements in implementing an IT framework in emerging economies.

Chapter 6. Role of the Exchange Rate: Freedman, Laxton and Ötker-Robe (2009) discusses the role of the exchange rate in an IT regime.

Chapter 7. Forecasting and Policy Analysis System: Laxton, Rose and Scott (2009) sets out the process for developing a structured forecasting and policy analysis system.

Chapter 8. Research and Advanced Macro Modeling: Laxton, Rose and Schmidt-Hebbel (2009) examine the role of research and DSGE modeling under IT.

Chapter 9. Modeling at the Central Bank of Chile: Schmidt-Hebbel (2009) discusses the experiences with modeling at the central bank of Chile.

Chapter 10. Country Experiences with the Introduction and Implementation of Inflation Targeting: Freedman and Ötker-Robe (2009b) presents selected country experiences with IT, including a summary of lessons learned from country experiences based on detailed case studies prepared by the national central bank representatives. 


\section{References}

Alichi, A., H. Chen, K. Clinton, C. Freedman, M. J. Johnson, O. Kamenik, T. Kişinbay, and D. Laxton, 2009, "inflation-Forecast Targeting Under Imperfect Policy Credibility," IMF Working Paper No. 09/94, available at www.imf.org.

Archer, D., 2005, "Central-Bank Communication and the Publication of Interest Rate Projections," in Inflation Targeting: Implementation, Communication and Effectiveness, Sveriges Riksbank Conference, available at www.riksbank.com/templates/Page.aspx $? \mathrm{id}=20327$

Bank of England, 1999, Economics Models at the Bank of England.

Blinder, A., C. A. E. Goodhart, D. Lipton, and C. Wiplosz, 2001, "How Do Centrals Banks Talk?" Geneva Report on the World Economy No. 3, Center for Economic Policy Research.

Blinder, A. S., M. Ehrmann, M. Fratzscher, J. De Haan, and D.-J. Jansen, 2008, "Central Bank Communication and Monetary Policy: A Survey of Theory and Evidence," Journal of Economic Literature, December, pp. 910-945.

Edey, M. and A. Stone, 2004, "A Perspective on Monetary Policy Transparency and Communication," in The Future of Inflation Targeting, Reserve Bank of Australia 2004 Conference, pp. 73-100.

Freedman, C., 2002, "The Value of Transparency in Conducting Monetary Policy," Federal Reserve Bank of St. Louis, Review, July/August, pp. 155-60.

Freedman, C., D. Laxton, and I. Ötker-Robe, 2009, “On Developing a Full-Fledged Inflation Targeting Regime: Doing What You Say and Saying What you Do," forthcoming Internet Book on Inflation Targeting.

_ 2009, "Role of the Exchange Rate," forthcoming IMF Working Paper (Washington, DC.: International Monetary Fund) and Chapter 6 of On Implementing Full-Fledged Inflation-Targeting Regimes: Saying What You Do and Doing What you Say, unpublished manuscript by C. Freedman, D. Laxton and I. Ötker-Robe.

Freedman, C., and D. Laxton, 2009a, “Why Inflation Targeting?," IMF Working Paper No. 09/86 (Washington, DC.: International Monetary Fund) and Chapter 2 of On Implementing Full-Fledged Inflation-Targeting Regimes: Saying What You Do and Doing What you Say, unpublished manuscript by C. Freedman, D. Laxton and I. Ötker-Robe. 
, 2009b, “IT Framework Design Parameters,” IMF Working Paper No. 09/87 (Washington, DC.: International Monetary Fund) and Chapter 3 of On Implementing Full-Fledged Inflation-Targeting Regimes: Saying What You Do and Doing What you Say, unpublished manuscript by C. Freedman, D. Laxton and I. Ötker-Robe.

, 2009c, "Inflation Targeting Pillars: Transparency and Accountability," IMF Working Paper (Washington, DC: International Monetary Fund) and Chapter 4 of $O n$ Implementing Full-Fledge Inflation-Targeting Regimes: Saying What You Do and Doing What You Say, unpublished manuscript by C. Freedman, D. Laxton, and I. Ötker-Robe.

Freedman, C., and I. Ötker-Robe, 2009a, "Important Elements for Emerging Economies," forthcoming IMF Working Paper (Washington, DC.: International Monetary Fund) and Chapter 5 of On Implementing Full-Fledged Inflation-Targeting Regimes: Saying What You Do and Doing What you Say, unpublished manuscript by C. Freedman, D. Laxton and I. Ötker-Robe.

— 2009b, "Country Experiences with the Introduction and Implementation of Inflation Targeting," IMF Working Paper No. 09/161 (Washington, DC.: International Monetary Fund) and Chapter 10 of On Implementing Full-Fledged Inflation-Targeting Regimes: Saying What You Do and Doing What you Say, unpublished manuscript by C. Freedman, D. Laxton and I. Ötker-Robe.

Heenan, G., P. Marcel and S. Roger, 2006, "Implementing Inflation Targeting: Institutional Arrangements, Target Design, and Communications," IMF Working Paper No. 06/278, available at www.imf.org.

Ingves, S., 2007, “Introduction on Monetary Policy," Presentation to Riksdag Committee on Finance, February 22, available at www.riksbank.se/templates/Page.aspx?id=23966.

Isard, Peter and Douglas Laxton, 2000, "Issues Relating to Inflation Targeting and the Bank of England's Framework," in IMF Staff Country Report No. 00/106, (Washington: International Monetary Fund) pp. 5-45.

Jeanneau, S., 2009, "Communication of monetary policy decisions by central banks: what is revealed and why," BIS Papers No 47, May.

Jenkins, P., 2001, “Communicating Canadian Monetary Policy: Towards Greater Transparency," Bank of Canada Review, Summer, pp. 45-50.

Laxton, D., D. Rose and K. Schmidt-Hebbel, 2009, "Research and Advanced Macro Modeling," forthcoming IMF Working Paper (Washington, DC.: International Monetary Fund) and Chapter 8 of On Implementing Full-Fledged Inflation-Targeting Regimes: Saying What You Do and Doing What you Say, unpublished manuscript by C. Freedman, D. Laxton and I. Ötker-Robe. 
Laxton, D., D. Rose and A. Scott, 2009, “Developing a Structured Forecasting and Policy Analysis System,” IMF Working Paper No. 09/65, available at www.imf.org.

_ 2009, "Forecasting and Policy Analysis System," forthcoming IMF Working Paper (Washington, DC.: International Monetary Fund) and Chapter 7 of On Implementing Full-Fledged Inflation-Targeting Regimes: Saying What You Do and Doing What you Say, unpublished manuscript by C. Freedman, D. Laxton and I. Ötker-Robe.

Mishkin, F. S., 2004, “Can Central Bank Transparency Go Too Far?” in The Future of Inflation Targeting, Reserve Bank of Australia 2004 Conference, pp. 48-65.

Roger, S. and M. Stone, 2005, “On Target? The International Experience with Achieving Inflation Targets," IMF Working Paper No. 05/163, available at www.imf.org.

Schmidt-Hebbel, K., 2009, "Modeling at the Central Bank of Chile," forthcoming IMF Working Paper (Washington, DC.: International Monetary Fund) and Chapter 9 of $O n$ Implementing Full-Fledged Inflation-Targeting Regimes: Saying What You Do and Doing What you Say, unpublished manuscript by C. Freedman, D. Laxton and I. Ötker-Robe.

Svensson, L. E. O., 2007, "Monetary Policy and the Interest Rate Path," speech presented at Danske Bank, Stockholm, August 22, available at www.riksbank.se/templates/Page.aspx $? i d=25561$.

Vickers, J., 1998, “Inflation Targeting in Practice: the UK Experience,” Bank of England Quarterly Bulletin, November, pp. 368-75.

Winkler, B., 2002, "Which Kind of Transparency? On The Need for Clarity in Monetary Policy-Making," IFO Studien, Jg 48, Nr 3, pp. 401-27.

Woodford, M., 2005, “Central-Bank Communication and Policy Effectiveness," in Inflation Targeting: Implementation, Communication and Effectiveness, Sveriges Riksbank Conference, available at www.riksbank.com/templates/Page.aspx ?id=20327. 